\title{
STUDI KOMPARASI AKHLAK SISWA BERTEMPAT TINGGAL DI DALAM DAN DI LUAR PONDOK PESANTREN
}

\author{
Oleh: \\ Eneng Sugiarti, Hidayah Baisa \\ Universitas Ibn Khaldun Bogor \\ enengsugiarti95@gmail.com
}

\begin{abstract}
Morals are the main thing that must be considered by every human being. Because with morals, people will be judged to be good or bad. Moreover morals determine the harmony between people. Environment is the main factor of the morals formation in every human being. If the environment is good then the probability of morality reflected will also be good. And otherwise, if the environment is bad it will most likely affect the morality os the community. But morals can be changed if people try the best to make it better. This study aims to determine the morals of students who live in Islamic Boarding Schools, an also determine the morals of students who live outside the boarding school and to find out wether or not there are moral defferencee between students who live in Islmaic Boarding Schools and the student who live outside. The type used in this study is a type quantitative research. Data collection techniques in this study are documentation and questionaries with 155 students. As for the analysis, the researcher used a comparative techniques of different test (T-test) T-test free sample (Independent sample T-test). But before it, data was tested for Validity and Reability first. The result of the study conclude there are moral differences between students who live outside boarding school with a Sig. (2-tailed) of 0,000<0,05, which means that the null hypothesis (Ho) is rejected and the alternative hypothesis (Ha) is Accepted. This difference is based on differences in students residence, so students will have a noble characters with a deeper religous learning and living environment which always invites in goodness.
\end{abstract}

Keywords: moral students, residence, boarding school

\begin{abstract}
Abstrak
Akhlak adalah hal utama yang harus diperhatikan oleh setiap manusia, karena dengan akhlak manusia akan dinilai baik atau buruk bahkan akhlakpun sangat menentukan kerukunan antar masyarakat, lingkungan merupakan faktor utama pembentukan akhlak pada setiap manusia, jika lingkungannya baik maka kemungkinan besar akhlak yang tercerminpun akan baik pula. Dan sebaliknya, jika lingkungannya tidak baik maka kemungkinan besar akan berpengaruh terhadap akhlak masyarkat tersebut, tapi akhlak dapat diubah jika manusia berusaha bersungguh-sungguh untuk mengubahnya menjadi lebih baik. Penelitian ini bertujuan untuk mengetahui akhlak siswa yang tinggal di pondok pesantren, untuk mengetahui akhlak siswa yang tinggal di luar pondok pesantren dan untuk mengetahui ada atau tidaknya perbedaan akhlak antara siswa yang tinggal di pondok pesantren dengan siswa yang tinggal di luar pondok pesantren. Jenis yang digunakan dalam penelitian ini adalah jenis penelitian kuantitatif. Teknik pengumpulan data dalam penelitian ini adalah dokumentasi dan angket dengan sempel siswa sebanyak 155 orang. Sedangkan untuk analisa, peneliti menggunakan teknik
\end{abstract}


komparasi Uji Beda (t-test) T-test sempel bebas (Independent Sample T Test), namun sebelumnya, data diuji validitas dan reabilitas terlebih dahulu. Hasil penelitian menyimpulkan bahwa terdapat perbedaan akhlak siswa yang tinggal di pondok pesantren dengan siswa yang tinggal di luar pondok pesantren yaitu dengan nilai Sig. (2-tailed) sebesar $\mathbf{0 , 0 0 0}<\mathbf{0 , 0 5}$ yang berarti hipotesis nol (Ho) ditolak dan hipotesis alternatif (Ha) diterima. Perbedaan ini didasari oleh perbedaan tempat tinggal siswa, jadi siswa akan berakhlak mulia dengan pembelajaran agama yang lebih mendalam dan lingkungan tempat tinggal yang selalu mengajak dalam kebaikan.

Keywords: akhlak siswa, tempat tinggal, pondok pesantren

\section{Pendahuluan}

Dalam proses pendidikan di sekolah, siswa sebagai subjek didik dan merupakan pribadi-pribadi yang unik dengan berbagai karakteristik. Siswa sebagai individu yang dinamis, karena kedinamisannya ini siswa selalu berada dalam proses perkembangan dari waktu ke waktu. Mulai dari dinamis dalam berfikir, berperasaan dan bertingkah laku.

Manusia merupakan makhluk ciptaan Allah SWT sebagai makhluk yang mulia dan sempurna dari pada makhluk yang lainnya. Dengan kesempurnaan itu maka manusia diberi amanat untuk menjadi khalifah Allah di muka bumi. Manusia diberi tugas yang sangat mulia dari Allah yaitu untuk menciptakan kemaslahatan di muka bumi ini dengan melaksanakan perintah-perintah Allah dan menjauhi larangan-larangan Allah yang merupakan bentuk pengabdian sekaligus akhlak seorang hamba terhadap Tuhannya.

Dari Sahl bin Sa'ad radiyallahu 'anhu; Rasulullah $S A W$ bersabda:

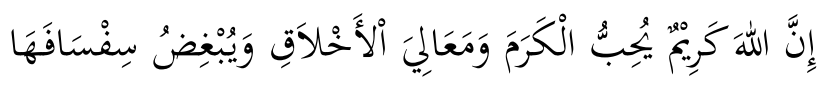

Sesungguhnya Allah Maha Pemurah menyukai kedermawanan dan akhlak yang mulia serta membenci akhlak yang rendah/hina. (HR. Muslim).

Islam mengajarkan pemeluknya agar memiliki akhlak yang luhur dan mulia, agar mendapatkan kebahagiaan dalam hidupnya. Pendidikan akhlak sangat diperlukan bagi kehidupan manusia untuk kelangsungan hidup yang bertujuan untuk membangun akhlak manusia yang sesuai dengan tuntunan Al-Qur'an dan Hadits. Dengan akhlak akan tercipta keserasian hubungan antara manusia dengan manusia dan manusia dengan lingkungannya. Akhlak akan menjadikan manusia serasi dan mengatur keseimbangan antara kepentingan dunia dan akhirat. 
Sekarang ini yang menjadi permasalahan yang dihadapi masyarakat adalah kemerosotan akhlak yang terjadi pada generasi muda. Yang pada dasarnya memang tidak terlepas dari tanggung jawab orang tua. Walaupun semua itu terjadi karena faktorfaktor lain di luar lingkungan keluarga seperti lingkungan masyarakat dan lingkungan sekolah. Kemerosotan akhlak dapat kita lihat di berbagai macam media, seperti media sosial yang sekarang sudah merajalela di kalangan pelajar, media televisi, media cetak dan lain-lain.

Pendidikan pada dasarnya sebagai proses pembelajaran yang ditujukan untuk mengembangkan potensi peserta didik. Konsep dasar dan pelaksanaannya akan ikut menentukan jalannya pendidikan di tengah kehidupan manusia. Pendidikan yang dalam pelaksanaannya melahirkan suatu konsep pemindahan pengalaman kepada peserta didik, kegiatan pemindahan pengalaman serta mengembangkannya itu kemudian menempati tempat khusus dalam proses pembelajaran. Pendidikan bukanlah kata yang asing di telinga masyarakat awam sekalipun. Karena seiring dengan laju perkembangan zaman, masyarakat Indonesia semakin tersadarkan tentang pentingnya pendidikan. Pendidikan bagi kehidupan umat manusia merupakan kebutuhan mutlak yang harus dipenuhi sepanjang hayat. Tanpa pendidikan sama sekali, mustahil suatu kelompok manusia dapat mengalami hidup dan berkembang sejalan dengan aspirasi (cita-cita) untuk maju, sejahtera dan bahagia menurut konsep pandangan hidup masing-masing. Sebagaimana Allah SWT. berfirman

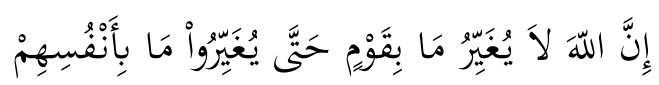

Sesungguhnya Allah tidak merubah keadaan suatu kaum sehingga mereka merubah keadaan yang ada pada diri mereka sendiri. (QS. Ar-Ra'd : 11)

Maka dari itu melalui pendidikan manusia diharapkan dapat meningkatkan kualitas dirinya, menjadi manusia yang sesuai dengan fitrahnya, dan sesuai dengan tujuan penciptaan manusia itu sendiri yang telah Allah SWT. tentukan. Manusia yang berpendidikan harus dapat melakukan perubahan-perubahan menuju peningkatan kualitas diri, Karena Allah SWT. tidak akan merubah keadaan manusia tanpa melalui usaha yang sungguh-sungguh. Berupa menjalankan segala perintah Allah SWT. dan menjauhi segala larangan-Nya. Madrasah merupakan sekolah yang di dalamnya mempelajari ilmu agama secara rinci baik praktik ibadah, muamalah serta akhlak, akan tetapi pembelajaran di madrasah tidak tertinggal pula ilmu umum seperti sekolah 
lainnya, madrasah salah satu lembaga pendidikan yang dapat membantu kerinduan orang tua muslim untuk mendapatkan pendidikan Islam yang baik untuk anak-anaknya.

Keunggulan pada mata pelajaran agama sebagai ciri khas tentu saja tidak hanya menekankan pada teoritis, yang sifatnya semata-mata untuk pengembangan ilmu pengetahuan, penting untuk diperhatikan bahwa madrasah memiliki ciri khas lain yang sangat menarik yaitu sekaligus pembinaan jiwa beragama dan akhlak yang lebih tinggi terhadap peserta didik. Oleh karena itu masyarakat seharusnya dapat dipelihara dari tindakan-tindakan kriminal anggota masyarakat yang merupakan cerminan dari akhlak yang buruk. Tindak kriminal juga kerap terjadi di lingkungan pendidikan seperti sekolah, universitas bahkan pesantren sekalipun. Tindakan tersebut tidak hanya dilakukan oleh si pendidik kepada peserta didik saja. Bahkan banyak juga peserta didik yang melakukan kriminal kepada si pendidik, dan terjadi juga diantara peserta didik, yang secara logika seharusnya lingkungan pendidikan terhindar dari perilaku kriminal, karena di dalamnya diselenggarakan dengan memberi keteladanan kepada peserta didik.

Bahkan Rasulullah SAW. diutus ke muka bumi sebagai tauladan umat manusia, sebagaimana Allah SWT. berfirman dalam Al-Qur'an surat Al-Ahzab ayat 21

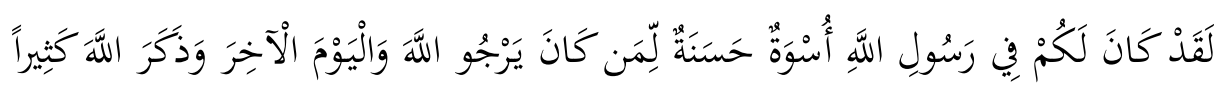

Sesungguhnya telah ada pada (diri) Rasulullah itu suri teladan yang baik bagimu (yaitu) bagi orang yang mengharap (rahmat) Allah dan (kedatangan) hari kiamat dan dia banyak menyebut Allah.

Dari ayat di atas menjelaskan bahwasannya Rasulullah $S A W$. adalah seorang yang kuat imannya, berani, sabar, tabah menghadapi segala macam cobaan, percaya dengan sepenuhnya kepada segala ketentuan-ketentuan Allah dan beliaupun mempunyai akhlak yang mulia. Jika mereka bercita-cita ingin menjadi manusia yang baik, bahagia hidup di dunia dan akhirat, tentulah mereka akan mencontoh dan mengikuti Nabi. Akhlak yang buruk lebih mendominan dari aklak yang baik sehingga banyak orang yang tidak bisa mengontrol dirinya dengan baik, dan banyak kasus-kasus yang muncul akibat dari akhlak buruk. ${ }^{1}$

Adanya pendidikan di madrasah dan pesantren diharapkan peserta didik mampu mengenali penciptanya, alam semesta dan manusia baik itu dirinya sendiri maupun

\footnotetext{
${ }^{1}$ Tim Badan Wakaf UII, Al-Qur'an dan Tafsir, Yogyakarta: PT. Dana Bhakti Wakaf, 1995, h. $743-744$
} 
oranglain, dengan demikian peserta didik akan menjadi manusia yang seutuhnya. Selain madrasah, pondok pesantren juga merupakan salah satu lembaga pendidikan yang berperan sebagai mitra dari orang tua dalam membantu program pendidikan dan pembinaan akhlak pada anak. Dengan adanya pendidikan pondok pesantren, maka diharapkan mampu mempertahankan akhlak manusia agar berakhlak baik, dan bisa menyeru kepada manusia lain untuk berbuat baik, karena dalam pesantren para santri secara khusus diajarkan ilmu agama bagaimana seharusnya manusia berhubungan baik dengan Allah SWT., dan berhubungan baik dengan manusia. Hal tersebut dikaji melalui kitab-kitab akhlak yang ada di pondok pesantren.

Pentingnya masalah ini untuk diteliti adalah untuk mengetahui tujuan dari pendidikan yaitu mengembangkan potensi diri untuk memiliki akhlak mulia. Penelitian ini untuk mengetauhui ada atau tidaknya perbedaan akhlak antara siswa yang tinggal di pondok pesantren dengan siswa yang tinggal di luar pondok pesantren. Penelitian ini mempunyai relevansi dan kegunaan keilmuan sesuai dengan jurusan Pendidikan Agama Islam sebagai referensi dan gambaran tentang perbandingan akhlak siswa sehingga pendidikan agama Islam tidak hanya mengejar tingginya nilai hasil belajar, tetapi juga mendidik siswa agar memiliki akhlak yang mulia. Oleh karena itu penulis memilih judul "Studi Komparasi Akhlak Siswa yang Tinggal Di Pondok Pesantren Dengan Siswa yang Tinggal Di Luar Pondok Pesantren, Studi Kasus MTs. Al-Karimiyah Depok" untuk mengetahui gambaran tentang ada atau tidaknya perbedaan akhlah antara siswa yang tinggal di pondok pesantren dan siswa yang tinngal di luar pondok pesantren.

\section{Metode Penelitian}

Dalam penelitian ini peneliti menggunakan pendekatan kuantitatif. penelitia kuantitatif adalah "penelitian yang banyak menggunakan angka, mulai dari pengumpulan data, penafsiran terhadap data tersebut serta penampilan dari hasilnya". ${ }^{2}$ Metode yang digunakan dalam penelitian ini adalah metode komparatif, yang mana peneliti akan mengkomparasikan akhlak antara siswa yang tinggal di pondok pesantren dengan siswa yang tinggal di pondok pesantren. Menurut Dra. Aswarni Sudjud dalam buku Suharismi Arikunto "Peneltian komparasi akan dapat menemukan persamaan-

\footnotetext{
${ }^{2}$ Suharismi Arikunto, Prosedur Penelitian Suatu Pendekatan Praktik Cet. Ke-15, Jakarta: PT. Rineke Cipta, 2014, h. 27
} 
persamaan dan perbedaan-perbedaan tentang benda-benda, tentang orang, tentang prosedur kerja, tentang ide-ide, kritik terhadap orang lain, kelompok, terhadap suatu ide atau suatu prosedur kerja". ${ }^{3}$ Maka dari itu dengan menggunakan metode komparatif, peneliti akan mengetahui ada atau tidak perbedaannya akhlak siswa yang tinggal di pondok pesantren dengan siswa yang tinggal di luar pondok pesantren. Adapun tempat dan waktu penelitian ini dilakukan di MTs. Al-Karimiyah yang beralamatkan di Jl. H. Maksum No.23 Sawangan Baru, Kota Depok, Jawa Barat. Sedangkan waktu penelitian ini dilaksanakan pada tanggal 11 Mei sampai 26 Juli 2018.

Dalam penelitian ini yang menjadi populasi yaitu seluruh siswa kelas VIII di MTs. Al-Karimiyah Depok dengan jumlah populasi 155 siswa dengan rincian 63 siswa yang tinggal di pondok pesantren dan 92 siswa yang tinggal di luar pondok pesantren. Karena jumlah populasi dari keduanya masing-masing kurang dari 100, oleh karena itu semua populasi dijadikan sampel yaitu sebanyak 155 responden, 63 siswa yang tinggal di pondok pesantren dan 92 siswa yang tinggal di luar pondok pesantren. Sampel dalam penelitian ini disebut juga dengan sampel jenuh atau total sampel. Teknik pengumpulan data yang digunakan adalah dokumentasi dan angket (kuesioner). Dalam penelitian ini penulis menggunakan teknik dokumentasi dalam rangka mengumpulkan data-data sebagai pendukung, dan angket (kuesioner) sebagai teknik utama dalam penelitian ini, digunakan untuk mengetahui perbedaan akhlak siswa yang tinggal di pondok pesantren dengan siswa yang tinggal di luar pondok pesantren. terdapat 30 butir kuesioner yang dibagikan kepada 63 siswa yang tinggal di pondok pesantren sebagai variabel $\mathrm{X}_{1}$, dan 92 siswa yang tinggal di luar pondok pesantren sebagai variabel $\mathrm{X}_{2}$. Jadi seluruhnya terdapat 155 siswa (responden) yang mengisi angket dalam pengawasan peneliti, dan cara untuk pemberian skor peneliti menggunakan skala Likert atau skala empat (4). Sedangkan untuk analisis data penulis menggunakan teknik komparasi Uji Beda ( $t$-test) T-test sempel bebas (Independent Sample T Test) dan diolah menggunakan SPSS 20.

\section{Hasil dan Pembahasan}

Akhlak (khuluq) adalah watak yang diperoleh seseorang dari pergaulannya dengan orang lain atau atas bimbingan orang tua dan pihak-pihak yang bertanggung jawab dalam proses pendidikan. ringkasannya, akhlak adalah watak yang diusahakan.

\footnotetext{
${ }^{3}$ Ibid, h. 310
} 
berbeda dengan al-khim yang berarti watak bawaan atau segala yang dilakukan manusia yang muncul dari nalurinya. ${ }^{4}$

Terdapat lima ciri perbuatan akhlak: (1) Perbuatan akhlak adalah perbuatan yang telah tertanam dalam jiwa seseorang sehingga telah menjadi kepribadiannya. (2) Perbuatan akhlak adalah perbuatan yang dilakukan dengan mudah dan tanpa pemikiran. (3) Perbuatan akhlak adalah perbuatan yang timbul dalam diri orang yang mengerjakannya tanpa ada apaksaan atau tekanan dari luar (4) Perbuatan akhlak adalah perbuatan yang dilakukan dengan sunggguh, bukan main-main atau sebagai sandiwara saja. (5) Akhlak baik adalah perbuatan yang dilakukan karena ikhlas (semata-mata) karena Allah, bukan karena ingin dipuji atau ingin mendapatkan suatu pujian. Sebagaimana. ${ }^{5}$ Rasulullah SAW. bersabda :

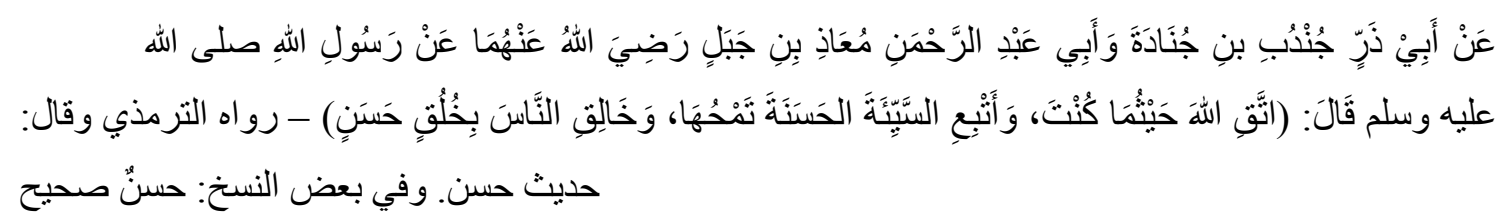

Dari Abu Dzar, Jundub bin Junadah dan Abu 'Abdurrahman, Mu'adz bin Jabal radhiyallahu 'anhuma, dari Rasulullah Shalallahu 'alaihi wa sallam, beliau bersabda: "Bertakwalah kepada Allah dimanapun kamu berada. dan ikutilah kejelekan dengan kebaikan, niscaya kebaikan itu akan menghapusnya. Dan bergaulilah manusia dengan akhlak terpuji." (HR. Tirmidzi, dan ia berkata : ini adalah hadits hasan, dan disebagian kitab disebutkan sebagai hadits hasan shahih). ${ }^{6}$

Sudjoko Prasodjo mendefinisikan bahwa pesantren adalah lembaga pendidikan dan pengajaran Islam non klasikal, dimana kiyai mengajarkan ilmu agama kepada santri, berdasarkan kitab yang ditulis dalam bahasa arab dan para santri tinggal di pondok dalam pesantren tersebut. ${ }^{7}$

Persyaratan-persyaratan pokok suatu lembaga dapat disebut pesantren maka harus ada sedikitnya 5 elemen yaitu, Pondok, masjid, santri, kiai dan pengajaran kitabkitab klasik, merupakan lima elemen dasar yang dapat menjelaskan secara sederhana

\footnotetext{
${ }^{4}$ Abuddin Nata, Akhlak Tasawuf Cet. 11, Jakarta: Rajawali Pers, 2012, h. 2

${ }^{5}$ Kasmuri Selamat dan Ihsan Sanusi, Akhlak Tasawuf Upaya Meraih Kehalusan Budi dan Kedekatan Ilahi, Jakarta: Kalam Mulia, 2012, h. 2

${ }^{6}$ Imam An-Nawawi, Terjemah Hadits Arba'in An-Nawawi cet.ke-8, Jakarta : Al-I'tishom Cahaya Umat, 2008, h. 28

${ }^{7}$ Ahmad Syafi'ie Noor, Orientasi Pengembangan Pendidikan Pesantren Tradisional, Jakarta : Prenada Media Group, 2009, h. 24
} 
apa sesungguhnya hakikat pesantren itu, yang membedakannya dengan lembaga pendidikan lainnya. ${ }^{8}$

Pada penelitian komparasi akhlak siswa yang tinggal di pondok pesantren dengan siswa yang tinggal di luar pondok pesantren, peneliti menggunakan teknik komparasi Uji Beda (t-test) T-test sempel bebas (Independent Sample T Test). untuk mengetahui ada atau tidaknya perbedaan akhlak siswa yang tinggal di pondok pesantren sebagai variabel $\mathrm{X}_{1}$ dengan siswa yang tinggal di luar pondok pesantren sebagai variabel $\mathrm{X}_{2}$, dijelaskan dalam tabel di bawah ini.

Tabel 1 : Hasil Uji Beda (T test) $\mathrm{X}_{1}$ dan $\mathrm{X}_{2}$

Independent Samples Test

\begin{tabular}{|c|c|c|c|c|c|c|c|c|c|c|}
\hline & & \multicolumn{2}{|c|}{$\begin{array}{l}\text { Levene's Test } \\
\text { for Equality of } \\
\text { Variances }\end{array}$} & \multicolumn{7}{|c|}{ t-test for Equality of Means } \\
\hline & & \multirow[t]{2}{*}{$\mathrm{F}$} & \multirow[t]{2}{*}{ Sig. } & \multirow[t]{2}{*}{$t$} & \multirow[t]{2}{*}{$\mathrm{df}$} & \multirow[t]{2}{*}{$\begin{array}{l}\text { Sig. (2- } \\
\text { tailed) }\end{array}$} & \multirow[t]{2}{*}{$\begin{array}{c}\text { Mean } \\
\text { Difference }\end{array}$} & \multirow{2}{*}{$\begin{array}{c}\text { Std. } \\
\text { Error } \\
\text { Differen } \\
\text { ce }\end{array}$} & \multicolumn{2}{|c|}{$\begin{array}{l}95 \% \text { Confidence } \\
\text { Interval of the } \\
\text { Difference }\end{array}$} \\
\hline & & & & & & & & & Lower & Upper \\
\hline \multirow{2}{*}{ Akhlak } & $\begin{array}{l}\text { Equal } \\
\text { variances } \\
\text { assumed }\end{array}$ & \multirow[t]{2}{*}{4.044} & \multirow[t]{2}{*}{.046} & \multirow[t]{2}{*}{6.062} & \multirow{2}{*}{$\begin{array}{r}153 \\
\\
150.4 \\
08\end{array}$} & \multirow[t]{2}{*}{.000} & \multirow{2}{*}{$\begin{array}{l}10.98758 \\
10.98758\end{array}$} & \multirow{2}{*}{$\begin{array}{l}1.81255 \\
1.73080\end{array}$} & \multirow{2}{*}{$\begin{array}{l}7.40672 \\
7.56775\end{array}$} & \multirow{2}{*}{$\begin{array}{r}14.5684 \\
4 \\
\\
14.4074 \\
0\end{array}$} \\
\hline & $\begin{array}{l}\text { Equal } \\
\text { variances not } \\
\text { assumed }\end{array}$ & & & & & & & & & \\
\hline
\end{tabular}

Dasar pengambilan keputusan dalam penelitian ini yaitu, jika nilai Sig. (2-tailed) $<0,005$, maka terdapat perbedaan yang signifikan antara akhlak siswa yang tinggal di pondok pesantren (variabel $\mathrm{X}_{1}$ ) dengan siswa yang tinggal di luar pondok pesantren (variabel $\mathrm{X}_{2}$ ), dan jika nilai Sig. (2-tailed) > 0,005 maka tidak terdapat perbedaan yang signifikan antara akhlak siswa yang tinggal di pondok pesantren (variabel $\mathrm{X}_{1}$ ) dengan siswa yang tinggal di luar pondok pesantren (variabel $\mathrm{X}_{2}$ ).

Berdasarkan hasil perhitungan di atas di peroleh nilai Sig. (2-tailed) sebesar 0,000, yang berarti nilai Sig. (2-tailed) $0,000<0,005$, maka dapat diketahui bahwa terdapat perbedaan yang signifikan antara akhlak siswa yang tinggal di pondok pesantren (variabel $\mathrm{X}_{1}$ ) dengan siswa yang tinggal di luar pondok pesantren (variabel $\mathrm{X}_{2}$ ). Adapun hipotesis yang diajukan dalam penelitian ini, yaitu: Ha yang berart terdapat

\footnotetext{
${ }^{8}$ Ferdinan, Pondok Pesantren, Ciri Khas Perkembangannya, Jurnal Tarbawi, Vol. 1, No. 1, h. 15
} 
perbedaan akhlak siswa yang tinggal di pondok pesantren dengan siswa yang tinggal di luar pondok pesantren dan Ho yang berarti tidak ada perbedaan akhlak siswa yang tinggal di pondok pesantren dengan siswa yang tinggal di luar pondok pesantren. Dengan kriteria pengujian, jika nilai Sig. (2-tailed) $<0,005$ maka Ha diterima dan Ho ditolak (terdapat perbedaan) dan jika nilai Sig. (2-tailed) > 0,005 maka Ho diterima dan Ha ditolak (tidak terdapat perbedaan). Berdasarka hasil analisis Uji Beda (T-test) yaitu nilai Sig. (2-tailed) 0,000 $<0,005$ maka Ha diterima dan Ho ditolak, dengan itu hipotesis yang diajukan dalam penelitian ini diterima, yang berarti terdapat perbedaan yang signifikan antara akhlak siswa yang tinggal di pondok pesantren dengan siswa yang tinggal di luar pondok pesantren.

\section{Kesimpulan}

Berdasarkan hasil penelitian, pembahasan serta analisis yang telah penulis lakukan mengenai studi komparasi akhlak siswa yang tinggal di pondok pesantren dengan siswa yang tinggal di luar pondok pesantren, maka peneliti dapat mengambil kesimpulan bahwa ada perbedaan yang signifikan antara akhlak siswa yang tinggal di pondok pesantren dengan siswa yang tinggal di luar pondok pesantren kelas VIII MTs. Al-Karimiyah Depok. Hal ini dibuktikan dari hasil Uji Beda (t-test) T-test sempel bebas (Independent Sample T Test) yaitu dengan nilai Sig. (2-tailed) sebesar 0,000. Maka Hipotesis nol (Ho) ditolak, dan berarti Hipotesis alternatif (Ha) diterima.[]

\section{Daftar Pustaka}

Arikunto, Suharismi. Prosedur Penelitian Suatu Pendekatan Praktik, Cet. Ke-15, Jakarta: PT. Rineke Cipta, 2014.

Ferdinan. "Pondok Pesantren, Ciri Khas Perkembangannya", Jurnal Tarbawi, Vol. 1, No. 1.

Imam An-Nawawi, Terjemah Hadits Arba'in An-Nawawi cet.ke-8, Jakarta : Al-I'tishom Cahaya Umat, 2008.

Nata, Abuddin. Akhlak Tasawuf Cet. 11, Jakarta: Rajawali Pers, 2012.

Neolaka, Amos. Metode Penelitian dan Statistik, Bandung: PT Remaja Rosdakarya, 2016. 
Noor, Ahmad Syafi'ie. Orientasi Pengembangan Pendidikan Pesantren Tradisional, Jakarta : Prenada Media Group, 2009.

Selamat, Kasmuri. Ihsan Sanusi, Akhlak Tasawuf Upaya Meraih Kehalusan Budi dan Kedekatan Ilahi, Jakarta: Kalam Mulia, 2012.

Sugiyono. Metode Penelitian Pendidikan Pendekatan Kuantitatif, Kualitatif dan RND, Bandung: Alfabeta, 2016.

Syaodih, Nana Sukmadinata. (2016). Metode Penelitian Pendidikan, Bandung: PT Remaja Rosdakarya.

Tim Badan Wakaf UII, Al-Qur'an dan Tafsir, Yogyakarta: PT. Dana Bhakti Wakaf, 1995. 